\title{
Functional Performance of PLR 1 Amaranthus under Different Protected Environmental Conditions
}

\author{
A. D. Ashok ${ }^{1 *}$ and K. Sakthivel ${ }^{2}$ \\ ${ }^{1}$ Institute of Agriculture, Tamil Nadu Agricultural University, Kumulur - 621712, \\ Trichy, Tamilnadu, India \\ ${ }^{2}$ Vegetable Research Station, Tamil Nadu Agricultural University, Palur - 607102 \\ Cuddalore Dist., Tamilnadu, India \\ *Corresponding author
}

\section{A B S T R A C T}

\section{Keywords \\ Amaranthus, PLR 1, Protected structure, \\ Polyhouse, Shadenet, Yield parameters}

\section{Article Info}

Accepted: 07 September 2020 Available Online: 10 October 2020
The experiment was conducted at the Institute of Agriculture, Agricultural Engineering College and Research Institute, Tamil Nadu Agricultural University, Kumulur, Tamilnadu, India. The experiment was conducted in Completely Randomised Block Design with 3 treatments and 8 replications during rainy and summer seasons. Three different growing conditions such as Polyhouse (T1), Shadenet (T2) and open condition (T3) were fixed as three treatments. The variety used in the study was Amaranthus PLR 1. Parameters such as Plant height (cm), Leaf Weight (g), Stem weight (g), Root weight (g), Total plant weight $(\mathrm{g})$, Total green weight $(\mathrm{g})$, Plot yield $(\mathrm{kg})$ and Total yield $(\mathrm{t} / \mathrm{ha}$.) are recorded after harvest at $21^{\text {st }}$ day after sowing. In rainy season, maximum plant height $(25.68 \mathrm{~cm})$ at 21 DAP was recorded under shade net condition, followed by polyhouse condition $(23.57 \mathrm{~cm})$. Amaranthus grown under Polyhouse condition recorded significantly the highest in leaf weight $(1.23 \mathrm{~g})$, stem weight $(2.17 \mathrm{~cm})$, root weight $(0.53 \mathrm{~cm})$, total weight $(3.93 \mathrm{~cm})$, plot yield $(19.67 \mathrm{~kg})$ and yield $(8.50 \mathrm{t} / \mathrm{ha})$. It was followed by amaranthus grown under shadenet condition. In summer season, amaranthus grown under shade net recorded maximum values in all the observed parameter such as plant height $(24.47 \mathrm{~cm})$, leaf weight $(1.53 \mathrm{~g})$, stem weight $(2.36 \mathrm{~g})$, root weight $(4.62 \mathrm{~g})$, total weight $(4.62 \mathrm{~g})$, total green weight $(3.89 \mathrm{~g})$, plot yield $(19.32 \mathrm{~kg})$ and total yield $(9.60 \mathrm{t} / \mathrm{ha})$. It was followed by amaranthus grown under polyhouse condition. From these experimental findings, we conclude that the yield performances of Amaranthus PLR 1 are better under polyhouse during rainy season and under shadenet during summer conditions. The variation in the performance of Amaranthus under polyhouse and shadenet based on the season is proportional to the availability of optimum temperature and relative humidity for the crop in that seasonal condition.

\section{Introduction}

Increasing population and decreasing cultivable area conduced the production of food produces to be year around with high productivity, irrespective of season. Since, greens are highly perishable and yet no any post harvest handling technology was 
developed to improve shelf life of the greens, it is essential to cultivate green vegetables throughout the year to meet the demand. But in India, a wide climate diversity with peak summer and long monsoon period, it is not possible to get same yield in all seasons under open field condition. Green house technology, nowadays called as protected cultivation, a bestowment for horticulture, makes it possible to get increased, even yield in all seasons. The protected cultivation technology improves the qualitative character of the produces and fetches higher yield than open field condition. The one more advantage of protected cultivation is off-season production of vegetables, fruits and ornamentals (Kang et al., 2013).

Pertaining to the study of growth and development of greens under different growing condition, we are considering a leafy vegetable called Amaranthus polygonoides, commonly called tropical amaranth and Sirukeerai in Tamil. These plants are short with alternate leaves on the main stem. The leaves are small when compared to Amaranthus dubius (Mulaikeerai, in tamil), obovate with blunt bifurcated tip and have long petioles. The juncture of the stem base and root is dark pink in colour. From each leaf axil a miniature branch starts which has very small alternate leaves. The tender plants are uprooted 25 days after planting and the leaves and tender stems are used (Veeraragavathatham et al., 1991). Tamil Nadu Agricultural University released a variety called Amaranthus PLR 1 during 2013, first of its kind variety in Sirukeerai type. It is suitable for making all kind of vegetable recipes in Tamilnadu.

There are only limited studies were done on cultivation of amaranthus under protected condition. With this, our study was aimed to evaluate the growth and yield of PLR 1 Amaranthus (Sirukeerai) by comparing under different protected conditions and open condition.

\section{Materials and Methods}

The experiment was conducted in two seasons viz., Rainy season and Summer season at the Institute of Agriculture, Agricultural Engineering College and Research Institute, Tamil Nadu Agricultural University, Kumulur, Tamilnadu, India. The location of the experimental area is at $10^{\circ} 56^{\prime}$ 'North latitude and $78^{\circ} 49^{\prime}$ East longitude and an altitude of 70 meters MSL. The experiment was conducted in Completely Randomised Block Design with 3 treatments and 8 replications during rainy and summer seasons. Three different growing conditions such as Polyhouse (T1), Shadenet (T2) and open field condition (T3) were fixed as three treatments. The variety used in the study was Amaranthus PLR 1. Soil inside the polyhouse and shadenet were ploughed to a fine tilth and fumigation was done with $2 \%$ formaldehyde to control soil borne pathogens under protected structures. Raised beds are formed at $2 \times 1.5 \mathrm{~m}$ size, with single replication plot of $20 \mathrm{~m}^{2}$ area. Amaranthus seeds are mixed with 10 parts of sand and directly sown on raised bed by line sowing for easy observation. Standard horticultural practices (TNAU Crop Production Guide, 2019) and plant protection measures were followed. Parameters such as Plant height $(\mathrm{cm})$, Leaf Weight (g), Stem weight (g), Root weight (g), Total plant weight (g), Total green weight (g), Plot yield $(\mathrm{kg})$ and Total yield $(\mathrm{t} / \mathrm{ha}$.) are recorded after harvest at $21^{\text {st }}$ day after sowing.

The inference was drawn after comparing the calculated $\mathrm{F}$ values with the tabulated $\mathrm{F}$ values at $5 \%(\mathrm{P}=0.05)$ level of significance. The estimates of mean, variance and standard error were done as per Panse and Sukhatme (1978). 


\section{Results and Discussion}

Evaluation of growth and yield of PLR 1 Amaranthus under different growing conditions based on various growth and yield parameters during rainy season were shown in table 1. All parameters showed significant differences in all growing conditions. Maximum plant height $(25.68 \mathrm{~cm})$ at 21 DAP was recorded under shade net condition, followed by polyhouse condition $(23.57 \mathrm{~cm})$. Amaranthus grown under Polyhouse condition recorded significantly the highest in leaf weight $(1.23 \mathrm{~g})$, stem weight $(2.17 \mathrm{~cm})$, root weight $(0.53 \mathrm{~cm})$, total weight $(3.93 \mathrm{~cm})$, plot yield $(19.67 \mathrm{~kg})$ and yield $(8.50 \mathrm{t} / \mathrm{ha})$. It was followed by amaranthus grown under shadenet condition.
The maximum yield under protected structure is confined to the maintenance of optimum temperature throughout the season and increased relative humidity. This is in line with Nimje and Shyam (1993) who observed in tomato crop that the relative humidity was higher inside the greenhouse than in the open field which influenced growth and yield. Our experiment during rainy season was in line the experiment of Garde and Angad Prakash (2018). Among, the leafy vegetables they observed, amaranthus recorded higher germination percentage, and showed better performance with respect to most of the growth attributes of the plant under protected conditions as compared to open field conditions.

Table.1 Growth and yield of Amaranthus PLR 1 under different growing condition during rainy season

\begin{tabular}{|l|c|c|c|c|c|c|c|c|}
\hline Location & $\begin{array}{c}\text { Plant } \\
\text { height } \\
\text { (cm) }\end{array}$ & $\begin{array}{c}\text { Leaf } \\
\text { weight } \\
\mathbf{( g )}\end{array}$ & $\begin{array}{c}\text { Stem } \\
\text { weight } \\
\mathbf{( g )}\end{array}$ & $\begin{array}{c}\text { Root } \\
\text { weight } \\
(\mathbf{g})\end{array}$ & $\begin{array}{c}\text { Total } \\
\text { weight } \\
\mathbf{( g )}\end{array}$ & $\begin{array}{c}\text { Total green } \\
\text { weight }(\mathbf{g})\end{array}$ & $\begin{array}{c}\text { Plot yield } \\
\left(\mathbf{2 0} \mathbf{m}^{\mathbf{2}} \mathbf{)}\right.\end{array}$ & $\begin{array}{c}\text { Yield } \\
(\mathbf{t} / \mathbf{h a})\end{array}$ \\
\hline T1 -Polyhouse & 23.57 & 1.23 & 2.17 & 0.53 & 3.93 & 3.40 & 19.67 & 8.50 \\
\hline T2 -Shade net & 25.68 & 1.11 & 2.08 & 0.49 & 3.68 & 3.19 & 17.70 & 7.97 \\
\hline $\begin{array}{l}\text { T3-Open field } \\
\text { condition }\end{array}$ & 20.63 & 0.78 & 1.97 & 0.45 & 3.20 & 2.75 & 15.93 & 7.17 \\
\hline Mean & 23.29 & 1.04 & 2.07 & 0.49 & 3.60 & 3.11 & 17.77 & 7.88 \\
\hline SE.d & 0.30 & 0.03 & 0.01 & 0.00 & 0.04 & 0.04 & 0.22 & 0.08 \\
\hline CD & 0.65 & 0.06 & 0.03 & 0.01 & 0.10 & 0.09 & 0.48 & 0.17 \\
\hline
\end{tabular}

Table.2 Growth and yield of Amaranthus PLR 1 under different growing condition during summer season

\begin{tabular}{|c|c|c|c|c|c|c|c|c|}
\hline Location & $\begin{array}{c}\text { Plant } \\
\text { height } \\
(\mathrm{cm})\end{array}$ & $\begin{array}{c}\text { Leaf } \\
\text { weight } \\
\text { (g) }\end{array}$ & $\begin{array}{l}\text { Stem } \\
\text { weight } \\
\text { (g) }\end{array}$ & $\begin{array}{c}\text { Root } \\
\text { weight } \\
\text { (g) }\end{array}$ & $\begin{array}{c}\text { Total } \\
\text { weight } \\
\text { (g) }\end{array}$ & $\begin{array}{l}\text { Total green } \\
\text { weight }(g)\end{array}$ & $\begin{array}{c}\text { Plot yield } \\
\left(20 \mathrm{~m}^{2}\right)(\mathrm{kg})\end{array}$ & $\begin{array}{l}\text { Total } \\
\text { Yield } \\
\text { (t/ha) }\end{array}$ \\
\hline T1 -Polyhouse & 21.56 & 1.15 & 2.28 & 0.58 & 4.01 & 3.43 & 17.34 & 8.60 \\
\hline T2 -Shade net & 24.47 & 1.53 & 2.36 & 0.73 & 4.62 & 3.89 & 19.32 & 9.60 \\
\hline $\begin{array}{l}\text { T3 -Open field } \\
\text { condition }\end{array}$ & 18.24 & 0.95 & 2.19 & 0.45 & 3.59 & 3.14 & 15.95 & 7.90 \\
\hline Mean & 21.42 & 1.21 & 2.28 & 0.59 & 4.07 & 3.49 & 17.54 & 8.70 \\
\hline SE.d & 0.37 & 0.04 & 0.01 & 0.02 & 0.06 & 0.05 & 0.20 & 0.10 \\
\hline CD & 0.80 & 0.08 & 0.02 & 0.04 & 0.13 & 0.10 & 0.43 & 0.22 \\
\hline
\end{tabular}


The same experiment had done during summer have significance in the results, as shown in table 2. Amaranthus grown under shade net recorded maximum values in all the observed parameter such as plant height $(24.47 \mathrm{~cm})$, leaf weight $(1.53 \mathrm{~g})$, stem weight $(2.36 \mathrm{~g})$, root weight $(4.62 \mathrm{~g})$, total weight $(4.62 \mathrm{~g})$, total green weight $(3.89 \mathrm{~g})$, plot yield $(19.32 \mathrm{~kg})$ and total yield $(9.60 \mathrm{t} / \mathrm{ha})$. It was followed by amaranthus grown under polyhouse condition.

In both the seasons, open field condition shows minimum performance comparing other two conditions. It is in line with Hawthron and Pollard (1957) who reported in capsicum that the lowest yield under open field might be due to high temperature comparing the protected conditions.

The maximum plant height was recorded under shadenet in both seasons, which might be influenced by shade under the shadenet which is more than in polyhouse. This observation is in line with the report that in protected environments, shoots tend to elongate and internodal length increases compared to the open conditions (Ganesan, 2004; Ramesh and Arumugam, 2010).

In rainy season, the performance of amaranthus under shadenet is lesser compared to polyhouse, might be due to the effect of rain, which increases the soil moisture level and humidity more than optimum. Also, leafspot and root rot problem were observed under shadenet during rainy season, which might be influenced the yield in depreciation. Krishnakumary and Rajan (2006) have reported that environmental factors play a pivotal role in disease development. The incidence of leaf spot in Amaranthus is severe during the month of July due to the prevailing low temperature, high humidity and rainfall as recorded in this study also.
Likewise, efficiency of polyhouse is reduced during peak summer, because of increase in under cover vertical temperature. The performance of amaranthus during summer is comparatively higher in shadenet than polyhouse and open condition. Priya et al., (2002) reported the same in sweet pepper that the yield of the crop was higher under shadenet house due to high relative humidity, which enhanced vegetative growth and improved fruit production. Poly film increases the temperature by accumulation of solar radiation inside structures and shade reduces temperatures inside a structure by reducing the amount of solar energy that enters structures. Shade nets are often deployed over crops to reduce heat stress (Pérez et al., 2006).

In conclusion, from these experimental findings, we conclude that the yield performances of Amaranthus PLR 1 are better under polyhouse during rainy season and under shadenet during summer conditions. The variation in the performance of Amaranthus under polyhouse and shadenet based on the season is proportional to the availability of optimum temperature and relative humidity for the crop in that seasonal condition.

\section{References}

Ganesan, M. 2004. Effect of poly-greenhouse on plant microclimate and fruit yield of tomato. IE (I).J.-AG 80:12-16.

Garde, Angad Prakash and Kadam, A.S. 2018. Influence of different growing conditions of growth yield and quality of leafy vegetables. Thesis, Vasantrao Naik Maratwada Krishi Vidyapeeth, Parbhani.

Hawthron, L.R. and Pollard, H. 1957. Vegetable and flower seed production, Biakisten Company, New York.

Krishnakumary, K. and Rajan, S. 2006. 
Seasonal influence on leaf spot disease in amaranth Internat. J. agric. Sci. 2(2): (324-326)

Nimje, P.M. and Shyam, M. 1993. Effect of plastic Greenhouse on plant microclimate and vegetable production. Farm. Syst. 9: 13-19.

Panse, V.G. and Sukhatme, P.V. 1978. Statistical methods for agricultural workers. 3rd Ed. New Delhi: Indian Council of Agricultural Research.

Pérez, M., Plaza, B.M., Jiménez, S., Lao, M.T., Barbero, J. and Bosch, J.L. 2006. The radiation spectrum through ornamental net houses and its impact on the climate generated. Acta Hort. 719: 631-636.

Priya, W., Vijayakumar, M., Veeragavathatham, D., Jeyakumar, P. and Chezian, N. 2002. Effect of seasons and growth environments on paprika (Capsicum annum var. longum) growth and yield. South Indian Hortcult. 50(4-6):463-471.

Ramesh, K.S. and Arumugam, T. 2010. Performance of vegetables under naturally ventilated polyhouse condition. Mysore J. Agric. Sci. 44(4): 770-776.

TNAU Crop Production Guide. 2019. http://agritech.tnau.ac.in/pdf/HORTIC ULTURE.pdf

Veeraragavathatham D., Jawaharlal M., and Seemathini Ramadas. 1991. A guide on Vegetable Culture. Suri Associates, Coimbatore: 226.

Yunyan Kang, Yao-Chien Alex Chang, HyunSug Choi and Mengmeng Gu. 2013. Current and Future Status of Protected Cultivation Techniques in Asia. Acta Hortic. 987: 33-40. DOI: 10.17660/ActaHortic.2013.987.3

\section{How to cite this article:}

Ashok, A. D. and Sakthivel, K. 2020. Functional Performance of PLR 1 Amaranthus under Different Protected Environmental Conditions. Int.J.Curr.Microbiol.App.Sci. 9(10): 510-514. doi: https://doi.org/10.20546/ijcmas.2020.910.061 